\title{
Nacre Compared to Aragonite as a Bone Substitute: Evaluation of Bioactivity and Biocompatibility
}

\author{
Arthur Corrêa de Almeida ${ }^{a, b *}$, Alexandra Rodrigues Pereira da Silva ${ }^{a}$, \\ Arnaldo Nakamura Filho ${ }^{a}$, Marcela Davi de Carvalho ${ }^{c}$, Antônio Valadão Cardoso ${ }^{a, b}$
}

\author{
${ }^{a}$ Centro de Bioengenharia de Espécies Invasoras de Hidrelétricas - CBEIH, \\ Av. José Cândido da Silveira, 2000, Horto, CEP 31035-536, Belo Horizonte, MG, Brazil \\ ${ }^{b}$ Rede Temática em Engenharia de Materiais - REDEMAT, Praça Tiradentes, 20, Centro, \\ CEP 35400-000, Ouro Preto, $M G$, Brazil \\ ${ }^{c}$ Companhia Energética de Minas Gerais - CEMIG, Av. Barbacena, 1200, \\ Santo Agostinho, CEP 30190-131, Belo Horizonte, MG, Brazil
}

Received: October 22, 2014; Revised: March 30, 2015

\begin{abstract}
Aragonite is a metastable polymorph of calcium carbonate found in mollusk's shells, appearing in tiles and prismatic columns, cemented in a protein matrix - mainly proteins - that acts as a framework on which the aragonite is nucleated forming nacre, besides selecting the morphology of the nucleated cristaline phase. The presence of the mineralyzing organic matrix may affect osteoinductive properties of biogenic aragonite, hypothesis tested by combinated tests, comparing viability and bioactivity of biomineralizated aragonite and nacre. Bioactivity was observed by deposition of Ca-P (presumably calcium phosphate) on the surface of samples immersed in Simulated Body Fluid; biocompatibility was verified by adhesion with VERO cells; cytotoxicity and alkaline phosphatase activity assays were performed with human adipose stem cells (hASC). Samples were characterized by scanning electron microscopy and X-ray diffraction. Both materials showed similar behaviour on bioactivity assay; in contrast, exhibited different behaviours in the presence of hASC.
\end{abstract}

Keywords: aragonite, nacre, biocompatibility, bioactivity, osteogenesis

\section{Introduction}

The main aim of tissue engineering - a branch of the sciences that unites Materials Engineering and Biomedicine - is the production of materials that can substitute and/or induce advanced regenerative processes in damaged tissue ${ }^{1}$. Mechanical, industrial, biological and clinical aspects are taken into consideration such as biocompatibility, bioactivity, recruiting capacity and induction of cellular differentiation. These materials cannot move on towards in vivo tests before a battery of in vitro tests ${ }^{2-4}$, among which immersion assays and tests with cellular cultures can be singled out. The creation of protocols of flexible and reliable tests permits reduction of costs and time in their application, assisting in the optimization of this crucial stage in the conversion of a prototype into a product.

The need for biocompatible materials for clinical use has become of a growing concern, the focus of much of the recent biomedical research ${ }^{4-9}$. What would be the ideal material for the substitution or regeneration of damaged bone tissue? Does there exist, in fact, an ideal material? ${ }^{10,11}$

Various methodologies have been employed to check the bioactivity of materials, and the SBF (Simulated Body Fluid $)^{12,13}$ and the in vitro culture of cells, using the biomaterial as a substrate, deserve to be singled out ${ }^{14-16}$. Through the cultivation of specific cellular lines ${ }^{17}$ in contact with the

*e-mail: arth.correa@gmail.com biomaterial, information can be obtained with respect to the biocompatibility of the sample, verified by means of the proliferation and viability of the cells and by the observation of characteristics such as cellular morfology after a certain period of cultivation, cellular adhesion to the substrate and the latter's degradation.

Biomineralization is a highly successful process that consists in the production, in an intra and/or extracellular environment, of mineral compounds that fulfill structural and ionic storage functions ${ }^{18,19}$. The ceramics obtained by this process possess varied characteristics, and metastable polymorphs are widely employed by organisms, in addition to the temporary amorphous phases ${ }^{20,21}$.

In mollusc shells, the aragonite and the protein matrix form a composite material (mineral matrix + organic matrix) called nacre. Taking into account that the mechanisms behind the construction of the different biomineralized tissues occur in similar fashion, it seems coherent to seek out materials that can substitute or induce the regeneration of bone tissue in other biomineralizing organisms, and this explains the attention given to corals and molluscs with shells $5,6,20-36$

Thus, this work has sought, through the gathering and comparison of the characteristics of clinical interest, to find in the residues from malacoculture the potential for obtaining an industrial input of low ecological/economic impact. Nacre and biogenic aragonite are two materials of 


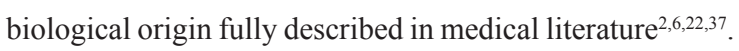
Both have been repeatedly analysed, by different authors, and present important osteogenic and mechanical properties. Raw nacre was continuously tested, and its osteogenic potential observed even in large bone defects ${ }^{25}$, without inflammation and/or fibrous formations. In vivo and in vitro studies indicate the nacre as a biocompatible, biodegradable and osteocondutive material, which may attract and activate bone marrow stem cells and osteoblasts; the same was observed in biogenic aragonite ${ }^{22-35}$. The mechanical and tribological properties - as tensile, compression and bending strength, besides resistance to abrasion - of the nacre, comparatively better than that of pure aragonite, are due to its hierarchical structure of micrometric hexagonal tablets with mineral bridges and interlocking surfaces ${ }^{36,38-42}$ and cemented in organic matrix. Considering that to this matrix are also attributed mineralizing and osteogenic properties ${ }^{22,30-34}$, the hypothesis raised initially was that the nacre would present more pronounced osteogenic properties than the aragonite, disregarding this study any differences in the mechanical properties.

\section{Materials and Methods}

\subsection{Preparation of samples}

The shells of the golden mussel (Limnoperna fortunei) were cleaned in running water and any fouling removed manually. After drying at room temperature, the shells were ground in a ball mill for $7 \mathrm{~h}$ at 70rpm, until fine particles were obtained. Half of the powder obtained was submitted to thermal treatment in an electric muffle at $400^{\circ} \mathrm{C}$ for $1 \mathrm{~h}$ to remove organic material ${ }^{36,38}$ The predominance of aragonite was confirmed by X-ray diffraction in Synchrotron Light at the National Synchrotron Light Laboratory - LNLS (Campinas/SP). The other half, with an organic matrix (nacre) was stored at room temperature.

The pastilles were produced with a manual pastillator and then cut into smaller pieces, approximately $5 \times 5 \times 5 \mathrm{~mm}$. The pastilles were maintained in shape during the tests by the application of a partial envelope of carnauba wax.

\subsection{Characterization}

The $\mathrm{CaCO}_{3}$ phases, like the transitions, were observed by X-ray diffraction (DRX) in Synchrotron Light at the LNLS (Campinas/SP). The morphology of the samples before and after the in vitro tests was examined using Scanning Electron Microscopy - SEM (TESCAN) after metallizing with gold/palladium. The composition of the material deposited after immersion in SBF was checked by Energy Dispersive Spectroscopy (EDS) attached to the SEM.

\subsection{In vitro tests}

\subsubsection{Bioactivity test}

Bioactivity was checked through tests of immersion in SBF.

$1000 \mathrm{~mL}$ of SBF were prepared ${ }^{13}$ by dissolving $5.403 \mathrm{~g}$ of $\mathrm{NaCl} ; 0.504 \mathrm{~g}$ of $\mathrm{NaHCO}_{3} ; 0.426 \mathrm{~g}$ of $\mathrm{Na}_{2} \mathrm{CO}_{3} ; 0.225 \mathrm{~g}$ of $\mathrm{KCl} ; 0.230 \mathrm{~g}$ of $\mathrm{K}_{2} \mathrm{HPO}_{4} \cdot 3 \mathrm{H}_{2} \mathrm{O} ; 0.311 \mathrm{~g} \mathrm{MgCl} \cdot 6 \mathrm{H}_{2} \mathrm{O}$; 17.892g of HEPES (2-(4-(2-hydroxyethyl)-1-piperazinyl) ethane sulfonic acid) previously dissolved in $100 \mathrm{~mL}$ of aqueous solution of $0.2 \mathrm{M}-\mathrm{NaOH} ; 0.293 \mathrm{~g}$ of $\mathrm{CaCl}_{2} ; 0.072 \mathrm{~g}$ of $\mathrm{Na}_{2} \mathrm{SO}_{4}$ and $1.5 \mathrm{~mL}$ of $\mathrm{NaOH}$ at $1 \mathrm{~mol} / \mathrm{L}^{-1}$ in bidistilled water. The $\mathrm{pH}$ was measured by a digital phmeter and maintained around 7.4.

After immersion (1 $\mathrm{g}$ of sample - in the form of a pastille - in $2 \mathrm{~mL}$ of SBF) the samples were maintained at $37^{\circ} \mathrm{C}$ in a heater and removed from the solution at different times, they being: 1, 5, 10, 17, 24 and 31 days. The solution was substituted every $48 \mathrm{~h}$. The tests of immersion in SBF were carried out in wellplates with 24 wells. All the samples were tested in quadruplicate.

\subsubsection{Cellular tests}

Two cellular types were used in the execution of the tests: VERO cells (isolated from kidney epithelial cells extracted from an African green monkey - Chlorocebus sp.) and hASC (human adipose stem cells). While the hASC were used in the tests of Viability and Cellular Proliferation (MTT) and Alkaline Phosphatase Activity, the VERO cells were used in the contact tests, a qualitative test, where the main parameter evaluated is cellular morphology - VERO cells are used as a standard because of the facility to observe changes in their morphology due to interactions with the substrate ${ }^{42}$.

\subsubsection{Contact test}

The VERO cells were sown in the samples (obtained in the form of pastilles) in the proportion $3 \times 10^{5}$ cells/well and incubated for $24 \mathrm{~h}$ at $37^{\circ} \mathrm{C}$ and $5 \% \mathrm{CO}_{2}$. In the exhaustion chamber $400 \mathrm{uL}$ of glutaraldehyde $2 \%$ in PBS $0.15 \mathrm{M}$ per well were added to fix the material. Were also added 3 pastilles of $\mathrm{NaOH}$ in other wells in the plate to neutralize the volatile toxic gases from the gluteraldehyde. The plate was sealed with parafilm and incubated for a further $16 \mathrm{~h}$ at $37^{\circ} \mathrm{C}$. After the fixing of the samples, the gluteraldehyde was aspirated into the exhaustion chamber and the wells were submitted to stages of increasing dehydration with 30,50 , 70 and $100 \%$ alcohols solutions for 30 minutes, for each solution, at room temperature. The fixed and dehydrated samples were finally metallized and taken to the scanning electron microscope for examination.

\subsubsection{Isolation and cultivation of the stem cells} from the human adipose tissue

The isolation and cultivation of the stem cells from the human adipose tissue (hASC) was carried out as described in the literature ${ }^{14-16,43}$. The hASC were obtained from the lipoaspirate of patients of the female sex, between 20 and 40 , submitted to liposuction surgery in conformity with the standards approved by the Ethics Committee in Research of the Federal University of Minas Gerais - UFMG (Opinion $\mathrm{n}^{\mathrm{o}}$ ETIC - 0107.0.203.000-10). The hASC were expanded to the fourth passage to be used in the experiments.

The culture medium used was DMEM (Sigma-Aldrich) supplemented with $5 \mathrm{mM}$ of sodium bicarbonate (Cinética Química Ltda.), 10\% of Fetal Bovine Serum (FBS - Cripion), 1000 units $/ \mathrm{mL}$ of penicillin, $1 \mathrm{mg} / \mathrm{mL}$ of streptomycin, $2,5 \mu \mathrm{g} / \mathrm{mL}$ of amphotericin B (Sigma-Aldrich) and $60 \mathrm{mg} / \mathrm{L}$ of gentamicin (Schering- Plough). The $\mathrm{pH}$ was adjusted 
to 7.2 and the medium was filtered with a polyvinylidene difluoride membrane of $0.22 \mu \mathrm{m}$ (Millipore).

\subsubsection{Cytotoxicity test}

Cytotoxicity of the biomaterials was measured by cell viability and proliferation through $\mathrm{MTT}^{44}$. The hASC cells were plated in the fourth passage in a 24 -well plates at a density of $1 \times 10^{4}$ cells per well. The cell populations were normalized with a DMEM medium for 24 hours. After this period the medium was changed and the samples placed in their respective wells.

The cells were incubated at $37^{\circ} \mathrm{C}$ in a humid atmosphere and $5 \% \mathrm{CO}_{2}$ for 24,72 and 120 hours. At the end of each incubation period, the culture medium was removed and discarded and $210 \mu \mathrm{L} /$ well of DMEM medium added. Then $170 \mu \mathrm{L} /$ well of MTT solution (Invitrogen) $(5 \mathrm{mg} / \mathrm{mL})$ and the cells were incubated at $37^{\circ} \mathrm{C}$, humid atmosphere and $5 \% \mathrm{CO}_{2}$, for 2 hours. The hASC were observed under an optical microscope to examine the formazan crystals. These were dissolved by the addition of $210 \mu \mathrm{L} /$ well of an SDS10\% - $\mathrm{HCl}$ (0.01M hydrochloric acid - $10 \%$ of sodium dodecyl sulfate in water) solution followed by incubation at $37^{\circ} \mathrm{C}$, humid atmosphere and $5 \% \mathrm{CO}_{2}$, for 18 hours. $100 \mu \mathrm{L}$ from each well were transferred to a 96 -well plate (flat bottomed), in triplicate, and the optical density measured in the spectrophotometer (Perkin Elmer Lambda 20) at $595 \mathrm{~nm}$. During the experiment, all the steps involving the MTT reagent were carried out under minimal conditions of luminosity. The results obtained were analysed by GraphPad Instat 3 (GraphPad Software Inc., San Diego, USA) software and the means were compared by SNK test.

\subsubsection{Alkaline Phosphatase Activity}

Alkaline phosphatase activity (ALP) was evaluated by means of the NBT/BCIP (Gibco) test ${ }^{45}$. The hASC cells were plated in the fourth passage in 24 -well plates at a density of $1 \times 10^{4}$ cells per well. The cell populations were normalized with a DMEM medium for 24 hours. After this period the medium was changed and the samples placed in their respective wells.

At the end of each incubation period, the culture medium was removed and discarded, the cells were washed with PBS 0,15M, pH 7.4 and incubated with $210 \mu \mathrm{L} /$ well of NBT/BCIP solution (prepared in accordance with the manufacturer's instructions) at $37^{\circ} \mathrm{C}$, humid atmosphere and $5 \% \mathrm{CO}_{2}$, for 2 hours.

After the incubation period, the formation of a purple precipitate was observed by optical microscope. Following this, $210 \mu \mathrm{L} /$ well of SDS $10 \%-\mathrm{HCl}$ were added to dissolve the purple precipitate. The plates were incubated at $37^{\circ} \mathrm{C}$, humid atmosphere and $5 \% \mathrm{CO}_{2}$, for 18 hours. $100 \mu \mathrm{L}$ from each well were transferred, in triplicate, to a 96-well plate (flat bottomed) and the optical density was measured in the spectrophotometer (Perkin Elmer Lambda 20) at 595nm. During the experiment, all the steps involving the NBT-BCIP reagents were carried out under minimal conditions of luminosity. The results obtained were analysed by GraphPad Instat 3 (GraphPad Software Inc., San Diego, USA) software and the means were compared by SNK test.

\section{Results}

\subsection{X-ray diffraction}

The graphs obtained by DRX (Figure 1) showed a phase transition of the $\mathrm{CaCO}_{3}$, which is converted, from about $300^{\circ} \mathrm{C}$, from aragonite to calcite ${ }^{38}$.

\subsection{In vitro experiments}

\subsubsection{Immersion in simulated body fluid}

The precipitation of calcium phosphate occurred in the same manner in the thermically treated samples as in those without treatment (Figure 2 and Figure 3). The appearance of a homogeneous covering was perceived initially. Subsequently, on this, points or agglomerates arise where the nucleation seems to occur preferentially, quite similar over the whole of the surface (Figure 4).

The composition of the material deposited was confirmed by EDS (Figure 5).

\subsubsection{Cell tests}

\subsubsection{Contact test}

Figure 6 presents the samples after immersion, for 24 hours, in a fibroblast cultural medium of VERO line. The slightly globular structures visible in the images are fibroblasts. The presence of filamentous structures of adhesion and anchorage, denominated pseudopodia (highlighted in Figure $6 \mathrm{c}$ ), indicates the fixation process of the cells to the substrate, denoting a relationship of biocompatibility desired in materials for clinical use.

\subsubsection{Cytotoxicity test}

Figure 7 presents the results of the MTT assays in thermically treated and untreated material (NT: samples without thermal treatment; T: samples thermically treated

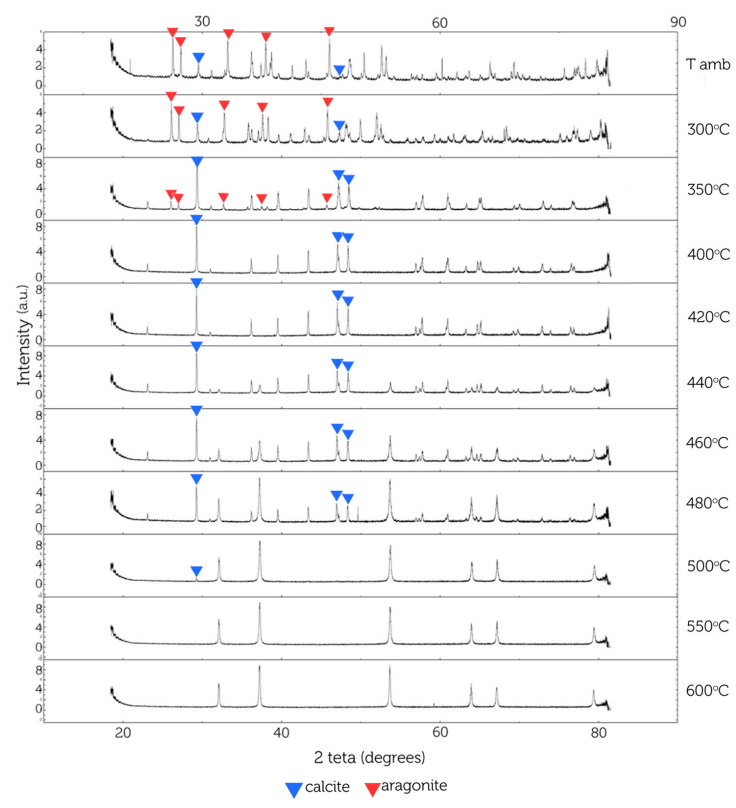

Figure 1. Graphs obtained by Synchrotron Light for samples of L.fortunei shells at different temperatures. 


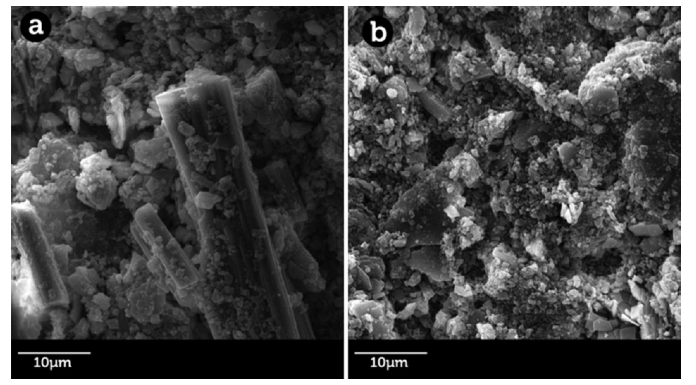

Figure 2. Pastilles immediately before soaking in SBF. a) NT Pastille. b) T Pastille. SEM.

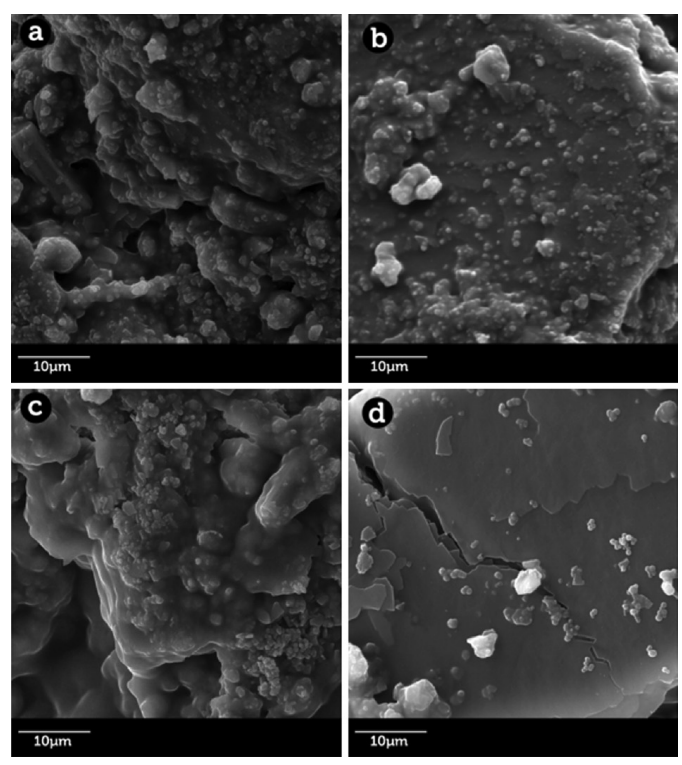

Figure 3. Immersion in SBF, day 1. a, b) Pastilles without treatment. c, d) Thermally treated pastilles. SEM.

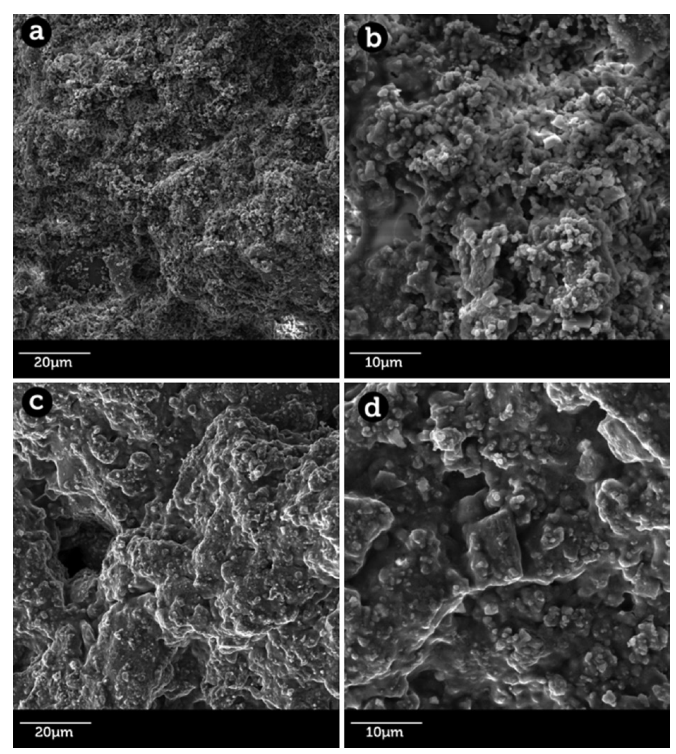

Figure 4. Micrograph of a pastille in the SBF Immersion assay, after the twenty-fourth day. a, b) Thermally treated pastilles. c, d) Untreated pastilles. SEM

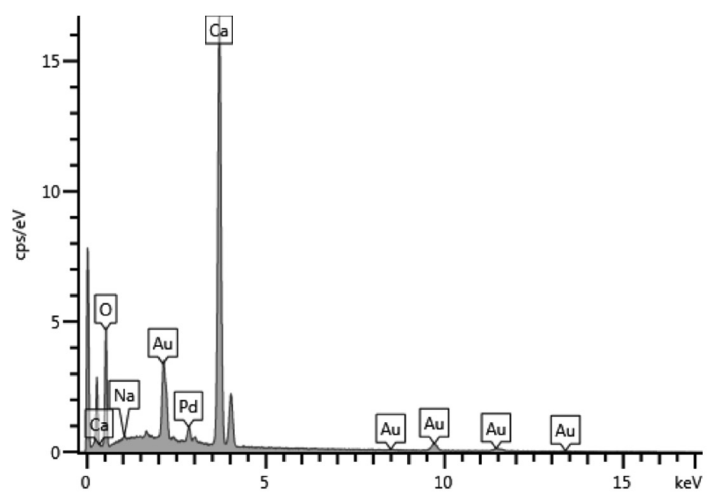

(a)

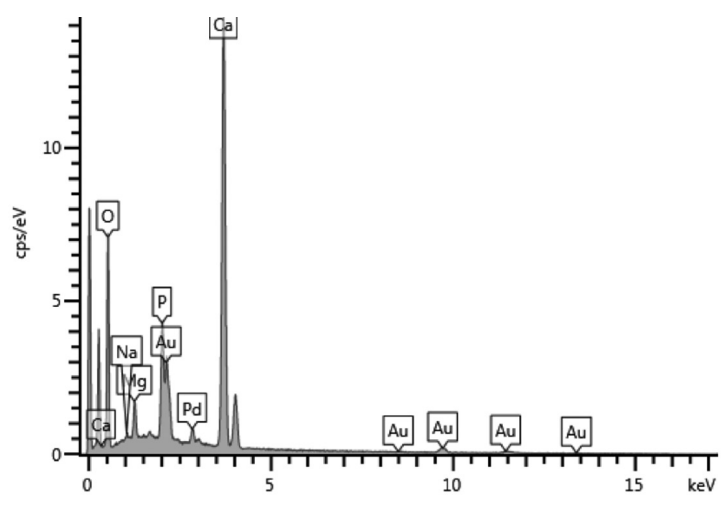

(b)

Figure 5. Results of the EDS (SEM) before immersion in SBF (a) and after immersion in SBF (b). Au and Pd relate to metallic cover applied over the sample for SEM preparation, while the presence of $\mathrm{P}$ in the post-immersion sample may indicate the presence of HA.

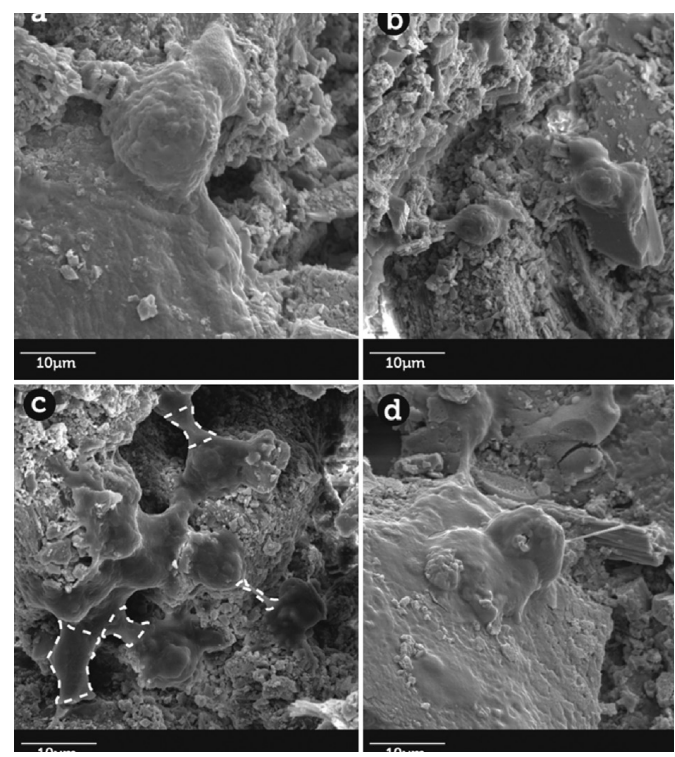

Figure 6. Pastilles exposed to the fribroblast culture of the VERO line. a, b) Pastilles without thermal treatment. c, d) Thermally treated pastilles. The arrows in c indicate pseudopodia. 
at $400^{\circ} \mathrm{C}$ for 60 minutes), further compared were shell fragments in natura, washed in deionized water. DMEM refers to the culture medium appropriate for the cell type in question, having an appropriate $\mathrm{pH}$ and nutritional factors. The absence of a substrate allows it to be used as a positive control, while C-corresponds to the negative control, where all the cells are dead, guaranteeing the inexistence of metabolic activity. In the tests with powdered samples, calcite samples were further tested, proposed today as a mineral charge in bone implants ${ }^{44-47}$.

Except for the T samples, which reached relative metabolic stability in 72 hours, the other samples maintained a growing level of metabolic stimulation in the period of 120 hours, mentioning especially the NT samples. It is known in the literature that the stem cells have high proliferative potential that gradually decreases as the cells commit to a cell lineage ${ }^{48}$.

In the MTT assays with powdered samples (Figure 8), the calcite stands out in the periods 72 and 120 hours. The NT and $\mathrm{T}$ samples show similar behaviour, inducing metabolic reduction in the period of 72 hours followed by an increase in the period of 120 hours, while the DMEM shows linear growth over the duration of the experiment, staying below all the substrates tested. Besides, these results suggest that all biomaterials tested presented an induced behaviour on hASC viability and proliferation when compared to cell proliferation in DMEM media, evidencing no cytotoxicity from the samples and all of them can be considered suitable for cell culture.

\subsubsection{Alkaline Phosphatase Activity}

The graph presented in Figure 9 shows the results obtained in the ALP tests with the pastilles manually pressed (NT and T) and shell fragments in natura, in addition to the positive (DMEM) and negative (C-) control. While the ALP production increases over time in the NT samples, the $\mathrm{T}$ samples remained relatively stable, as well as the shell samples in natura. The T samples presented an improved production of ALP in 24 and 72 hours when compared to cells cultivated DMEM media, suggesting this biomaterial can be able to induce an inicial change in hASC phenotype, when compared to other samples. To prove this hypothesis, additional tests should be performed. Alkaline phosphatase is an enzyme present in undifferentiated cells, therefore it is used as a stem cell marker, however, this enzyme is produced at high levels in early osteogenic differentiation, and is considered an early marker of differentiation ${ }^{49}$.

Taking into account that cells cultivated in $\mathrm{T}$ samples reached relative metabolic stability in MTT assay in 72 hours and produced high results of ALP at the same time, it can be suggested an inicial commitment of these cells towards an osteogenic phenotype.

In Figure 10, the graph shows the result of the tests with powdered samples. Taking into account that the NT samples are ground shells, the shell sample was substituted by calcite, also powdered, obtained by the heat treatment of the T sample in an electric muffle at $400^{\circ} \mathrm{C}^{36}$. The graph presented in Figure 10 presented very interesting results in respect to a potencial of these biomaterials related to osteogenic induction or differentiation. As mentioned before, only cells commited to osteogenic phenotype are able to

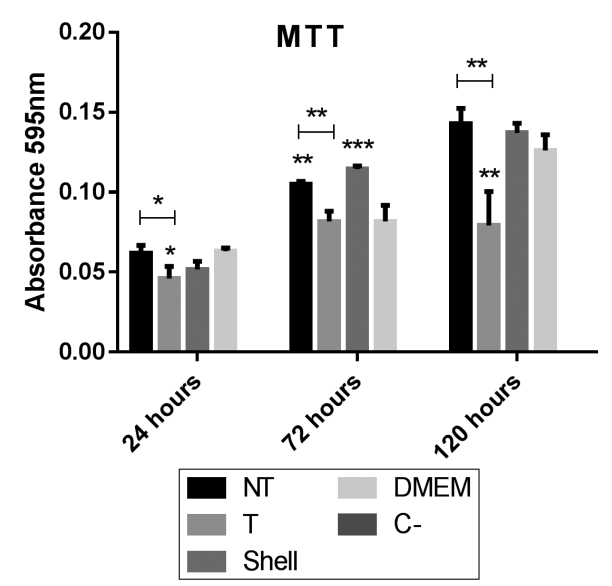

Figure 7. Results of the MTT assays in pastilles and fragments (Shell). Asterisks refer to the significance of the results, when compared to DMEM. Thus, * $* *$ or $* * *$ serve as a scale indicating how much the results differ from each sample DMEM.

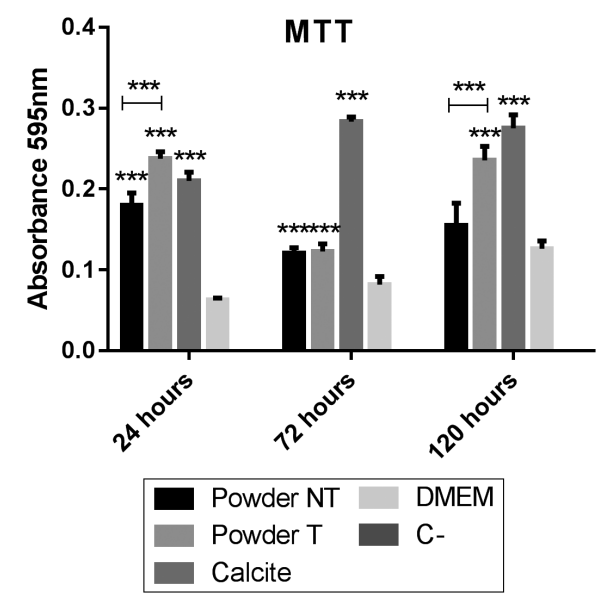

Figure 8. Results of the MTT assays in pulverized samples. Asterisks refer to the significance of the results, when compared to DMEM. Thus, *** serve as a scale indicating how much the results differ from each sample DMEM.

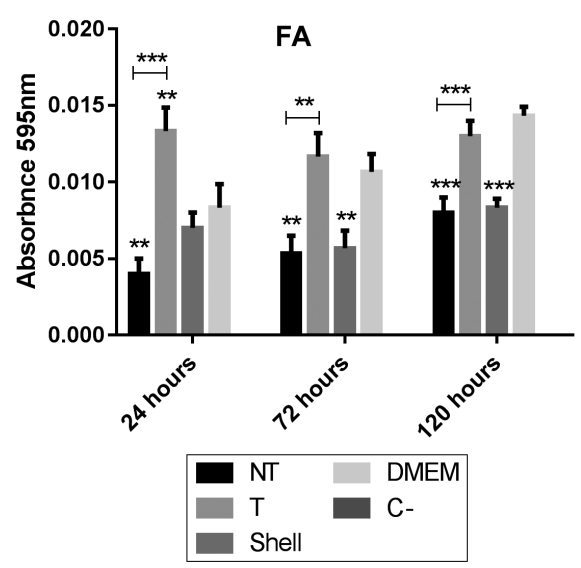

Figure 9. Results of the Alkaline Phosphatase tests with pastille or fragment (shells) samples. Asterisks refer to the significance of the results, when compared to DMEM. Thus, ${ }^{* *}$ or $* * *$ serve as a scale indicating how much the results differ from each sample DMEM. 


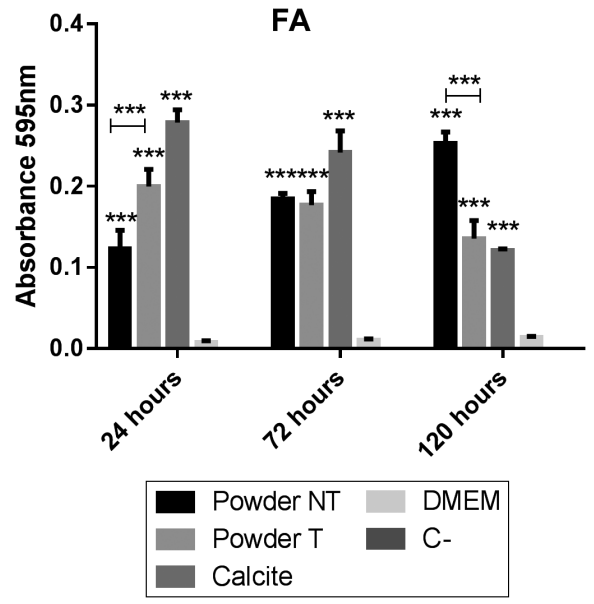

Figure 10. Results of the Alkaline Phosphatase tests with powdered samples. Asterisks refer to the significance of the results, when compared to DMEM. Thus, *** serve as a scale indicating how much the results differ from each sample DMEM.

produce high concentrations of ALP enzime. These results are believed due to the shape of the biomaterial introduced, where the powder has a larger contact surface, which considerably increases the leaching of calcium in the media and favors and/or accelerate the possibility of osteogenic cell induction or differentiation. When compared to cells cultivated in DMEM media, all biomaterials evidenced a significative higher production of ALP, specially a high increase in concentration at first 24 hours in cells cultivated in presence of calcite and at 120 hours in cells cultivated in NT powder were observed.

\section{Discussion}

Taking into account the comparative nature of the proposal, the bioactivity and biocompatibility tests were carried out to observe the behaviour of the materials of interest for subsequent comparison.

As previously stated, it was expected that the presence of the organic matrix in the untreated samples (nacre) would affect the response of the material in the different tests, relative to the thermically treated samples (aragonite) where the organic matrix is absent, due to the osteogenic properties inherent to the organic matrix ${ }^{22}$.

In the first experiment, immersion in SBF, followed by the scanning electron microscopy (SEM) of the samples, the bioactivity of the materials was confirmed. In accordance with similar experiments observed in the literature the quantity and size of the grains deposited act as somewhat quantitative indicators of the ability to induce precipitation of $\mathrm{Ca}-\mathrm{P}$ (confirmed by EDS), and observing the images obtained by SEM, no perceptible difference appears in the comparison between the two materials, within these parameters. The results of the experiments with SBF approached, visually, those obtained with other ceramic materials such as $\alpha$-tricalcium phosphate $(\alpha-\mathrm{TCP})$ and bi-phasic hydroxyapatite/ $\alpha$-tricalcium phosphate $(\mathrm{HA} / \mathrm{TCP})^{50}$, and better than the results obtained

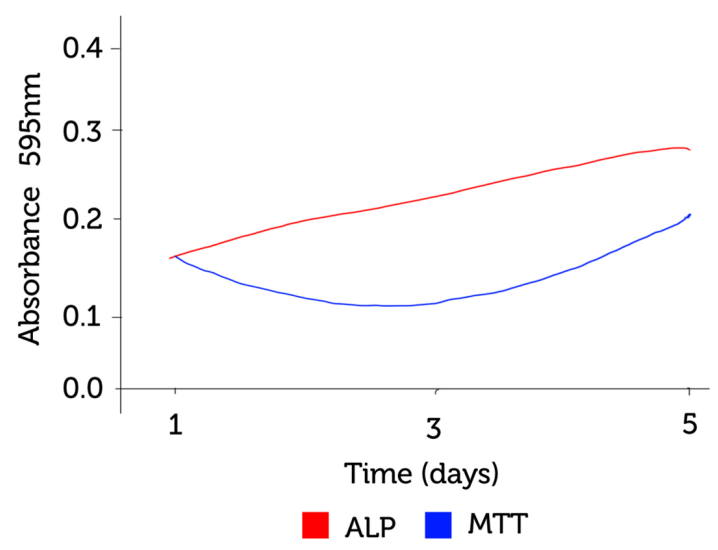

Figure 11. Graph showing the results of non-treated samples in Cytotoxicity tests (MTT) and Alkaline Phosphatase Activity (AP).

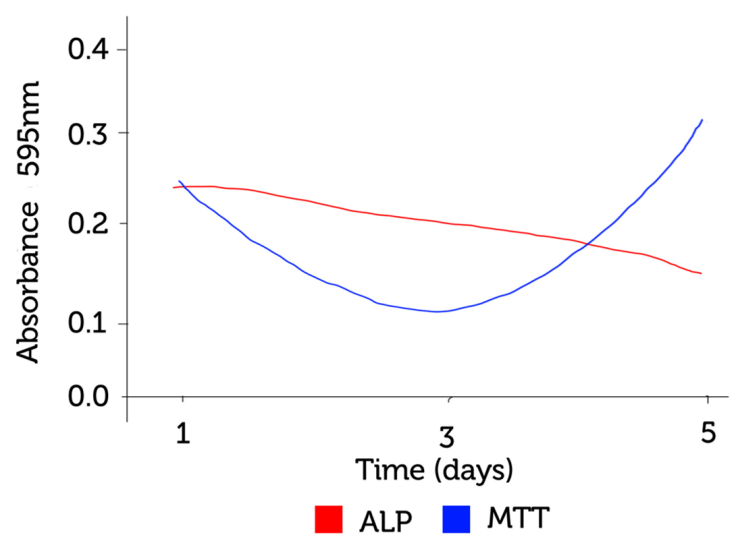

Figure 12. Graph showing the results of treated samples in Cytotoxicity tests (MTT) and Alkaline Phosphatase Activity (AP).

with sintered Bioglasss ${ }^{\circledR}(\mathrm{BG})^{51}$ and calcium phosphate monobasic monohydrate $\left[\mathrm{Ca}\left(\mathrm{H}_{2} \mathrm{PO}_{4}\right)_{2} \cdot \mathrm{H}_{2} \mathrm{O}\right]^{52}$.

In the contact tests with VERO cells there was also no difference between the samples. The biocompatible character of the materials is reinforced, even if there are no conclusive indexes, considering the absence of in vivo tests. Comparing the morphology of the cells with tests found in the literature, the materials tested in this work presented results similar to those obtained with composite materials such as 34Bio_10Poly_5Pe and 29Bio_12Poly (polyurethane sponge employed as an organic skeleton for the scaffolds, which were realized using 45S5 Bioglass $\left.{ }^{\circledR}\right)$, but they exceed the same materials in the cellular viability parameter after the first 24 hours $^{53}$, with results $>60 \%$, but lower than the $90 \%$ viability obtained with the hybrid Polyoxyethylene sorbitan laurate (TWEEN) plus graphene oxide (RGO) ${ }^{54}$. Also in relation to the morphology of the VERO cells, nacre and biomineralized aragonite exceed the results obtained with some titanium alloys, obtained by thermal and anodic oxidation and by the sol-gel technique, like cp-Ti and Ti1.5Al25V substrates ${ }^{55}$, and match those results collected on chitin/nBGC and chitosan/nBGC scaffolds review ${ }^{56}$. The 
use of osteoblastic cell lines can be a future step towards validation of the results in more specific cell lines.

However in the MTT and ALP assays considerable differences arose. Analyzing the results of the ALP tests, it can be seen that the calcite acts as a substrate with a high potential for cellular differentiation, nevertheless, this effect suffers a considerable reduction within the interval observed. This behaviour is repeated by the T samples (aragonite), on a smaller scale. Meanwhile, the NT samples (nacre) present the contrary behaviour, increasing the rates of differentiation of the bone tissue over the time interval.

Comparing the results of MTT, the cellular responses are inverted. While, over the interval observed, the calcite has reduced its capacity for cellular differentiation, its capacity to stimulate multiplication increases. The inversion of the rates is also observed in the NT samples.

NT: The production of Alkaline Phosphatase increases considerably with the passage of time, over the interval observed. In the corresponding period, the MTT reading suggests high rates of replication (in comparison with the positive control group, DMEM) at the start, followed by a small fall, coinciding with the increase in the PA readings (Figure 11).

T: Initially, the samples that underwent thermal treatment (aragonite) stimulate both the differentiation and cellular division, with very similar rates. The subsequent fall in the MTT and PA readings (Figure 12) may indicate a relative exhaustion of the cell culture.

Comparing the results of the MTT tests obtained with those found in the literature in relation to other bioceramics, the cellular viability of the nacre and the biomineralized aragonite, powdered, is close to the viability observed in akermanite $\left(\mathrm{Ca}_{2} \mathrm{MgSi}_{2} \mathrm{O}_{7}\right)$, as a $\mathrm{Ca}, \mathrm{Mg}$ and $\mathrm{Si}$ containing bioceramic and $\beta$-TCP in the period observed, in a culture of human bone marrow-derived stromal cells (hBMSCs) ${ }^{14}$.

\section{References}

1. Arcos D, Boccaccini AR, Bohner M, Díez-Pérez A, Epple M, Gómez-Barrena E, et al. The relevance of biomaterials to the prevention and treatment of osteoporosis. Acta Biomaterialia. 2014; 10(5):1793-1805. http://dx.doi.org/10.1016/j.actbio.2014.01.004. PMid:24418434

2. Vallet-Regí M and Arcos D. Biomimetic nanoceramics in clinical use: from materials to applications. Cambridge: RSC Publishing; 2008.

3. Combes C, Miao B, Bareille R and Rey C. Preparation, physical-chemical characterisation and cytocompatibility of calcium carbonate cements. Biomaterials. 2006; 27(9):19451954. http://dx.doi.org/10.1016/j.biomaterials.2005.09.026. PMid:16219345

4. Combes $\mathrm{C}$ and Rey C. Amorphous calcium phosphates: synthesis, properties and uses in biomaterials. Acta Biomaterialia. 2010; 6(9):3362-3378. http://dx.doi.org/10.1016/j.actbio.2010.02.017. PMid:20167295

5. Nakamura A Fo, Almeida AC, Riera HE, Araújo JLF, Gouveia VJP, Carvalho MD, et al. Polymorphism of $\mathrm{CaCO} 3$ and microstructure of the shell of a brazilian invasive mollusc (Limnoperna fortunei). Materials Research. 2014; 17(Suppl. 1):15-22. http://dx.doi.org/10.1590/S1516-14392014005000044.

\section{Conclusion}

Both biomaterials tested presented bioactivity and cytotoxicity rates compatible with the proposal to produce scaffolds for the substitution of damaged bone tissue, although in vivo tests are still indispensable for confirmation and advancing in this respect.

During the preparation of the hypothesis, the idea was broached that nacre, due to the presence of the organic matrix, would produce better osteogenic responses. However, throughout the constant bibliographical review and the adhesion assays, cytotoxicity and ALP activity, it could be seen that statements like "this or that material is the best" are superficial and do not take into account the varied factors that come together to obtain complex bone tissue. Thus, nacre and aragonite, together with other materials, form an increasingly large range of available materials, each with more or less marked properties, which can interact among themselves to obtain a composite material, capable of stimulating diverse responses in the body, in a chain of events, with the purpose of regenerating bone tissue preserving it's diverse characteristics.

\section{Acknowledgements}

We would like to thank the National Synchrotron Light Laboratory, the LNLS (Campinas/SP), Professor Edel Figueiredo Barbosa Stancioli and Mateus Laguardia of the Basic Applied Virology Laboratory (ICB/UFMG) and Professor Alfredo Miranda Góes of the Molecular and Cellular Immunology Laboratory (ICB/UFMG), for their support and willing help. We further thank Fapemig, the Foundation for the Support of Research of the State of Minas Gerais, Capes, the Coordination for the Development of High Level Personnel, the Gorceix Foundation and CEMIG/ANEEL.

6. Hoque ME, Shehryar M and Nurul Islam KM. Processing and characterization of cockle shell calcium carbonate $(\mathrm{CaCO} 3)$ bioceramic for potential application in bone tissue engineering. $J$ Material Sci Eng. 2013;2(4):132. http://dx.doi.org/10.4172/21690022.1000132 .

7. Karageorgiou V and Kaplan D. Porosity of 3D biomaterial scaffolds and osteogenesis. Biomaterials. 2005; 26(27):54745491. http://dx.doi.org/10.1016/j.biomaterials.2005.02.002. PMid:15860204

8. Garreta E, Gasset D, Semino C and Borrós S. Fabrication of a three-dimensional nanostructured biomaterial for tissue engineering of bone. Biomolecular Engineering. 2007; 24(1):75-80. http:// dx.doi.org/10.1016/j.bioeng.2006.05.017. PMid:16846750

9. Vallet-Regí M, Izquierdo-Barba I and Colilla M. Structure and functionalization of mesoporous bioceramics for bone tissue regeneration and local drug delivery. Philosophical Transactions. Series A, Mathematical, Physical, and Engineering Sciences. 2012; 370(1963):1400-1421. http://dx.doi.org/10.1098/ rsta.2011.0258. PMid:22349248

10. Saiz E, Zimmermann EA, Lee JS, Wegst UGK and Tomsia AP. Perspectives on the role of nanotechnology in bone tissue engineering. Dental Materials. 2013; 29(1):103-115. http:// dx.doi.org/10.1016/j.dental.2012.08.001. PMid:22901861 
11. Bose S, Roy M and Bandyopadhyay A. Recent advances in bone tissue engineering scaffolds. Trends in Biotechnology. 2012; 30(10):546-554. http://dx.doi.org/10.1016/j.tibtech.2012.07.005. PMid:22939815

12. Tanahashi M, Kokubo T, Nakamura T, Katsura $Y$ and Nagano M. Ultrastructural study of an apatite layer formed by a biomimetic process and its bonding to bone. Biomaterials. 1996; 17(1):47-51. http://dx.doi.org/10.1016/0142-9612(96)80754-X. PMid:8962947

13. Oyane A, Kim HM, Furuya T, Kokubo T, Miyazaki T and Nakamura T. Preparation and assessment of revised simulated body fluids. Journal of Biomedical Materials Research. Part A. 2003; 65(2):188-195. http://dx.doi.org/10.1002/jbm.a.10482. PMid:12734811

14. Davis JM. Basic cell culture. 2nd ed. New York: Oxford University Press; 2002.

15. Vunjak-Novakovic G and Freshney IR, editors. Culture of cells for tissue engineering. New Jersey: John Wiley \& Sons; 2006. http://dx.doi.org/10.1002/0471741817.

16. Freshney IR. Culture of animal cells: a manual of basic technique and specialized applications. Hoboken: Wiley-Blackwell; 2010. http://dx.doi.org/10.1002/9780470649367.

17. Huang Y, Jin X, Zhang X, Sun H, Tu J, Tang T, et al. In vitro and in vivo evaluation of akermanite bioceramics for bone regeneration. Biomaterials. 2009; 30(28):5041-5048. http:// dx.doi.org/10.1016/j.biomaterials.2009.05.077. PMid:19545889

18. Lowenstam HA and Weiner S. On biomineralization. New York: Oxford University Press; 1989.

19. Kelton KF and Greer AL. Nucleation in condensed matter: applications in materials and biology. Pergamon: Elsevier; 2010. v. 15.

20. Weiss IM, Tuross N, Addadi L and Weiner S. Mollusc larval shell formation: amorphous calcium carbonate is a precursor phase for aragonite. The Journal of Experimental Zoology. 2002; 293(5):478-491. http://dx.doi.org/10.1002/jez.90004. PMid: 12486808

21. Weiner S and Addadi L. Crystallization Pathways in Biomineralization. Annual Review of Materials Research. 2011; 41(1):21-40. http:// dx.doi.org/10.1146/annurev-matsci-062910-095803 .

22. Lamghari M, Almeida MJ, Berland S, Huet H, Laurent A, Milet $\mathrm{C}$, et al. Stimulation of bone marrow cells and bone formation by nacre: in vivo and in vitro studies. Bone. 1999;25(2, Suppl):91S94S. http://dx.doi.org/10.1016/S8756-3282(99)00141-6. PMid: 10458284

23. Silve C, Lopez E, Vidal B, Smith DC, Camprasse S, Camprasse $\mathrm{G}$, et al. Nacre initiates biomineralization by human osteoblasts maintained in vitro. Calcified Tissue International. 1992; 51(5):363-369. http://dx.doi.org/10.1007/BF00316881. PMid:1458341

24. Atlan G, Balmain N, Berland S, Vidal B and López E. Reconstruction of human maxillary defects with nacre powder: histological evidence for bone regeneration. Comptes Rendus de l'Académie des Sciences. Série III, Sciences de la Vie. 1997; 320(3):253-258. http://dx.doi.org/10.1016/S0764-4469(97)869338. PMid:9183443

25. Atlan G, Delattre O, Berland S, LeFaou A, Nabias G, Cot $\mathrm{D}$, et al. Interface between bone and nacre implants in sheep. Biomaterials. 1999; 20(11):1017-1022. http://dx.doi.org/10.1016/ S0142-9612(98)90212-5. PMid:10378801

26. Duplat D, Chabadel A, Gallet M, Berland S, Bédouet L, Rousseau M, et al. The in vitro osteoclastic degradation of nacre. Biomaterials. 2007; 28(12):2155-2162. http://dx.doi. org/10.1016/j.biomaterials.2007.01.015. PMid:17258312
27. Liao H, Mutvei H, Sjöström M, Hammarström L and Li J. Tissue responses to natural aragonite (Margaritifera shell) implants in vivo. Biomaterials. 2000; 21(5):457-468. http:// dx.doi.org/10.1016/S0142-9612(99)00184-2. PMid:10674810

28. Liao H, Mutvei H, Hammarström L, Wurtz T and Li J. Tissue responses to nacreous implants in rat femur: an in situ hybridization and histochemical study. Biomaterials. 2002; 23(13):26932701. http://dx.doi.org/10.1016/S0142-9612(01)00421-5. PMid:12059018

29. Shen Y, Zhu J, Zhang $H$ and Zhao F. In vitro osteogenetic activity of pearl. Biomaterials. 2006; 27(2):281-287. http:// dx.doi.org/10.1016/j.biomaterials.2005.05.088. PMid:16023711

30. Rousseau M, Pereira-Mouriès L, Almeida MJ, Milet $\mathrm{C}$ and Lopez E. The water-soluble matrix fraction from the nacre of pinctada maxima produces earlier mineralization of MC3T3-E1 mouse pre-osteoblasts. Comparative Biochemistry and Physiology. Part B, Biochemistry \& Molecular Biology. 2003; 135(1):1-7. PMid:12781967.

31. Rousseau M, Boulzaguet H, Biagianti J, Duplat D, Milet C, Lopez E, et al. Low molecular weight molecules of oyster nacre induce mineralization of the MC3T3-E1 cells. Journal of Biomedical Materials Research. Part A. 2008; 85(2):487-497. http://dx.doi.org/10.1002/jbm.a.31553. PMid:17729263

32. Heinemann F, Treccani L and Fritz M. Abalone nacre insoluble matrix induces growth of flat and oriented aragonite crystals. Biochemical and Biophysical Research Communications. 2006; 344(1):45-49. http://dx.doi.org/10.1016/j.bbrc.2006.03.150. PMid:16631428

33. Kim YW, Kim JJ, Kim YH and Rho JY. Effects of organic matrix proteins on the interfacial structure at the bone-biocompatible nacre interface in vitro. Biomaterials. 2002; 23(9):2089-2096. http:// dx.doi.org/10.1016/S0142-9612(01)00340-4. PMid:11996051

34. Pereira Mouriès L, Almeida M-J, Milet C, Berland S and Lopez E. Bioactivity of nacre water-soluble organic matrix from the bivalve mollusk Pinctada maxima in three mammalian cell types: fibroblasts, bone marrow stromal cells and osteoblasts. Comparative Biochemistry and Physiology. Part B, Biochemistry \& Molecular Biology. 2002; 132(1):217-229. http://dx.doi. org/10.1016/S1096-4959(01)00524-3. PMid:11997223

35. Gonzáles R, Merino N, Rodríguez P and Rodríguez VM. In Vivo transformation of a calcium carbonate (aragonite) based implant's biomaterial to bone. A histological, chemical and FT-IR study. Revista CENIC Ciências Biológicas. 2004; 35(1): 7-13.

36. Huang $\mathrm{Z}$ and $\mathrm{Li} \mathrm{X}$. Nanoscale structural and mechanical characterization of heat treated nacre. Materials Science and Engineering C. 2009; 29(6):1803-1807. http://dx.doi. org/10.1016/j.msec.2009.02.007.

37. Monchau F, Hivart P, Genestie B, Chai F, Descamps M and Hildebrand HF. Calcite as a bone substitute. Comparison with hydroxyapatite and tricalcium phosphate with regard to the osteoblastic activity. Materials science \& engineering. $C$, Materials for biological applications. 2013; 33(1):490-498. http://dx.doi.org/10.1016/j.msec.2012.09.019. PMid:25428100

38. Huang $\mathrm{Z}$ and Li X. Origin of flaw-tolerance in nacre. Scientific Reports. 2013; 3:1693. http://dx.doi.org/10.1038/srep01693. PMid:23603788

39. Xie L, Wang XX and Li J. The SEM and TEM study on the laminated structure of individual aragonitic nacre tablet in freshwater bivalve H. cumingii Lea shell. Journal of Structural Biology. 2010; 169(1):89-94. http://dx.doi.org/10.1016/j. jsb.2009.09.002. PMid:19733246

40. Lackner JM, Waldhauser W, Hartmann P, Major L and Kot M. WITHDRAWN: Bio-inspired wear protection of soft materials 
by hard films: mechanical and tribological properties of nacre and multilayer Ti-TiN films. Archives of Civil and Mechanical Engineering. 2003. In press. http://dx.doi.org/10.1016/j. acme.2013.10.004.

41. Hamza S, Slimane N, Azari Z and Pluvinage G. Structural and mechanical properties of the coral and nacre and the potentiality of their use as bone substitutes. Applied Surface Science. 2013; 264:485-491. http://dx.doi.org/10.1016/j.apsusc.2012.10.049.

42. Liao TT, Shi YL, Jia JW, Jia RW and Wang L. Sensitivity of morphological change of Vero cells exposed to lipophilic compounds and its mechanism. Journal of Hazardous Materials. 2010; 179(1-3):1055-1064. http://dx.doi.org/10.1016/j. jhazmat.2010.03.113. PMid:20427127

43. Zuk PA, Zhu M, Mizuno H, Huang J, Futrell JW, Katz AJ, et al. Multilineage cells from human adipose tissue: implications for cell-based therapies. Tissue Engineering. 2001; 7(2):211-228. http://dx.doi.org/10.1089/107632701300062859. PMid:11304456

44. Mosmann T. Rapid colorimetric assay for cellular growth and survival: application to proliferation and cytotoxicity assays. Journal of lmmunological Methods. 1983; 65(1-2):55-63. PMid:6606682.

45. Smejkal GB and Kaul CA. Stability of nitroblue tetrazolium-based alkaline phosphatase substrates. The Journal of Histochemistry and Cytochemistry. 2001; 49(9):1189-1190. http://dx.doi. org/10.1177/002215540104900914. PMid:11511689

46. Monchau F, Lefèvre A, Descamps M, Belquin-myrdycz A, Laffargue $P$ and Hildebrand HF. In vitro studies of human and rat osteoclast activity on hydroxyapatite, $\beta$-tricalcium phosphate, calcium carbonate. Biomolecular Engineering. 2002; 19(26):143-152. http://dx.doi.org/10.1016/S1389-0344(02)00023-0. PMid:12202175

47. Luz GM and Mano JF. Mineralized structures in nature: examples and inspirations for the design of new composite materials and biomaterials. Composites Science and Technology. 2010; 70(13):1777-1788. http://dx.doi.org/10.1016/j. compscitech.2010.05.013.

48. Mountford JC. Human embryonic stem cells: origins, characteristics and potential for regenerative therapy. Transfusion
Medicine (Oxford, England). 2008; 18(1):1-12. http://dx.doi. org/10.1111/j.1365-3148.2007.00807.x. PMid:18279188

49. Bruder SP, Jaiswal N, Ricalton NS, Mosca JD, Kraus KH and Kadiyala S. Mesenchymal stem cells in osteobiology and applied bone regeneration. Clinical Orthopaedics and Related Research. 1998;355S(355, Suppl):S247-S256. http://dx.doi. org/10.1097/00003086-199810001-00025. PMid:9917644

50. Yang Y, Yao Q, Pu X, Hou Z and Zhang Q. Biphasic calcium phosphate macroporous scaffolds derived from oyster shells for bone tissue engineering. Chemical Engineering Journal. 2011; 173(3):837-845. http://dx.doi.org/10.1016/j.cej.2011.07.029.

51. Xin R, Leng Y, Chen J and Zhang Q. A comparative study of calcium phosphate formation on bioceramics in vitro and in vivo. Biomaterials. 2005; 26(33):6477-6486. http://dx.doi. org/10.1016/j.biomaterials.2005.04.028. PMid:15992923

52. Ding Y, Wang J, Chen Y, Shi G, Yu X and Wan C. Immersion behaviour ff calcium polyphosphate in simulated body fluid. Applied Surface Science. 2008; 255(2):534-537. http://dx.doi. org/10.1016/j.apsusc.2008.06.097.

53. Bellucci D, Chiellini F, Ciardelli G, Gazzarri M, Gentile P, Sola A, et al. Processing and characterization of innovative scaffolds for bone tissue engineering. Journal of Materials Science. Materials in Medicine. 2012;23(6):1397-1409. http:// dx.doi.org/10.1007/s10856-012-4622-6. PMid:22441671

54. Park S, Mohanty N, Suk JW, Nagaraja A, An J, Piner RD, et al. Biocompatible, robust free-standing paper composed of a TWEEN/graphene composite. Advanced materials (Deerfield Beach, Fla.). 2010; 22(15):1736-1740. http://dx.doi.org/10.1002/ adma.200903611. PMid:20496406

55. Eisenbarth E, Velten D, Schenk-Meuser K, Linez P, Biehl V, Duschner $\mathrm{H}$, et al. Interactions between cells and titanium surfaces. Biomolecular Engineering. 2002; 19(2-6):243-249. http://dx.doi. org/10.1016/S1389-0344(02)00032-1. PMid:12202190

56. Jayakumar R, Menon D, Manzoor K, Nair SV and Tamura H. Biomedical applications of chitin and chitosan based nanomaterials - a short review. Carbohydrate Polymers. 2010; 82(2):227-232. http://dx.doi.org/10.1016/j.carbpol.2010.04.074. 